\title{
Analisis Sektor Agroindustri di Indonesia dengan Metode Input- Output dan Ekonometrika
}

\author{
(Analyzing Indonesia's Agro-industry Sector Using Input-Output and Econometrics Methods)
}

\author{
I Dewa Gede Merta Yasa ${ }^{1}$, Anugerah Karta Monika ${ }^{2}$ \\ ${ }^{1,2}$ Politeknik Statistika STIS \\ Jalan Otto Iskandardinata No. 64C, Jatinegara, Jakarta Timur Daerah Khusus Ibukota Jakarta 13330 \\ E-mail: 211709741@stis.ac.id
}

\begin{abstract}
ABSTRAK
Indikasi deindustrialisasi dini di Indonesia ditandai dengan kontribusi sektor industri pengolahan terhadap PDB yang mengalami penurunan dari tahun ke tahun sebelum Indonesia mengalami industrialisasi secara penuh. Salah satu solusi yang dapat dilakukan untuk mengatasi hal tersebut yaitu dengan mengembangkan sektor agroindustri secara optimal. Namun, pengembangan sektor agroindustri di Indonesia masih mengalami banyak kendala. Penelitian ini bertujuan untuk mengidentifikasi struktur output, struktur input, angka pengganda, dan subsektor unggulan dalam agroindustri serta faktor-faktor yang memengaruhi output subsektor unggulan agroindustri. Metode analisis yang digunakan yaitu analisis tabel input-output agroindustri Indonesia tahun 2018 dan analisis regresi data panel dengan individu subsektor unggulan agroindustri dalam 3 digit KBLI 2015 dan rentang waktu 2010-2018. Hasil analisis input-output menunjukkan bahwa (i) struktur output sektor agroindustri lebih banyak digunakan sebagai konsumsi akhir, (ii) struktur input sektor agroindustri didominasi oleh input antara, (iii) nilai pengganda output masing-masing subsektor agroindustri cukup tinggi, dan (iv) industri makanan dan minuman; industri tekstil dan pakaian jadi; dan industri kimia, farmasi, dan obat tradisional menjadi subsektor unggulan agroindustri di Indonesia. Selanjutnya, berdasarkan analisis regresi data panel, diperoleh bahwa variabel tenaga kerja, penanaman modal (PMA dan PMDN), modal tetap, bahan bakar, dan penggunaan listrik berpengaruh positif dan signifikan terhadap output subsektor unggulan agroindustri.
\end{abstract}

Kata kunci: agroindustri, subsektor unggulan, tabel input-output, regresi data panel

\begin{abstract}
The persistent decline of the share of the manufacturing sector over the years before it reaches its peak to become fully industrialized indicates the existence of Indonesia's premature deindustrialization. One of the alternatives to solve this issue is by maximizing the agro-industrial sector's development. However, empirical evidence reveals that its development is still experiencing several obstacles. This study aims to identify the output structure, input structure, output multiplier, the agro-industry's leading subsectors and the factors affecting its output. This paper uses the data of 3-digit agroindustry's leading subsectors in KBLI 2015 from 2010 to 2018 with the help of panel data regression. The results of the input-output analysis show that (i) majority of the output structure of the agro-industrial sector is used as final consumption, (ii) the input structure of the agro-industrial sector is dominated by intermediate inputs, (iii) the output multiplier value of each sub-sector is quite high, and (iv) the food and beverage industry; the textile and apparel industry; and the chemical, pharmaceutical and traditional medicine industries are the leading agro-industry subsectors in Indonesia. Furthermore, the outcome of the panel regression analysis performed indicate that variables of labors, investments (PMA and PMDN), fixed capital, fuel, and electricity have a positive and significant effect on the output of the agro-industry's leading subsectors.
\end{abstract}

Keywords: agro-industry, leading subsectors, input-output table, panel regression

\section{PENDAHULUAN}

Perubahan struktur ekonomi merupakan salah satu hal yang menjadi perhatian dalam pembangunan perekonomian suatu negara, tidak terkecuali Indonesia. Teori transformasi struktural oleh Hollis Chenery menyatakan bahwa suatu negara mengalami transformasi dari pertanian tradisional ke sektor industri sebagai mesin penggerak utama pertumbuhan ekonomi atau disebut dengan industrialisasi (Tambunan, 2000). Indonesia telah mengalami proses industrialisasi ini yang ditandai dengan penurunan pangsa sektor pertanian dalam pembentukan PDB dan peningkatan kontribusi sektor industri pengolahan (Tambunan dan Priyanto, 2005). Namun, industrialisasi yang terjadi di Indonesia tidak berjalan dengan optimal. Institute for Development of Economics and Finance (INDEF) menyatakan bahwa dalam sepuluh tahun terakhir Indonesia 
sedang mengalami deindustrialisasi (Sujiatmiko, 2018). Deindustrialisasi merupakan fenomena dimana sektor industri mengalami penurunan kontribusi terhadap pendapatan nasional (Jalilian \& Weiss, 2000).

Deindustrialisasi menjadi fenomena yang wajar dialami oleh suatu negara pada saat kontribusi sektor industri terhadap PDB negara tersebut sudah mencapai titik yang tinggi. Namun, deindustrialisasi di Indonesia terlalu cepat terjadi dibandingkan dengan berbagai kasus deindustrialisasi di negara lain. United Nation Industrial Development Organization (UNIDO) juga menyatakan bahwa suatu negara masuk ke dalam kategori negara industri apabila kontribusi sektor industri pengolahannya lebih dari 30 persen (Dewi, 2010). Namun, deindustrialisasi di Indonesia terjadi saat kontribusi sektor industri pengolahan baru mencapai sekitar 28 persen terhadap PDB yang terjadi pada tahun 2002, di mana kontribusinya terus mengalami penurunan hingga saat ini. Maka dari itu, deindustrialisasi yang terjadi di Indonesia tergolong sebagai deindustrialisasi dini karena terjadi sebelum Indonesia mencapai kematangan industri (Arifin, 2018).

Terjadinya deindustrialisasi dini ini dapat memperburuk kondisi perekonomian Indonesia dalam jangka panjang melalui berbagai aspek, salah satunya menyebabkan Indonesia kehilangan kesempatan untuk meningkatkan pertumbuhan ekonomi nasional secara optimal melalui pertumbuhan dinamika sektor industri pengolahan (Arifin, 2018). Oleh karena itu, deindustrialisasi dini yang terjadi di Indonesia merupakan sebuah masalah yang perlu diperhatikan. Upaya ini selaras dengan Rencana Pembangunan Jangka Menengah Nasional (RPJMN) tahun 2020-2024 yang menyatakan bahwa salah satu sasaran makro pembangunan di Indonesia yaitu share industri pengolahan sebesar 20,1-21,3 persen dan pertumbuhan industri pengolahan non migas sebesar 5,8-7,6 persen. Dengan demikian, diperlukan suatu solusi untuk mencapai target share dan pertumbuhan industri pengolahan dalam rangka mengatasi deindustrialisasi dini di Indonesia. Salah satu solusi yang dapat dilakukan yaitu melalui percepatan dan perluasan agroindustri. Agroindustri dipandang sebagai transisi yang tepat dalam menjembatani proses transformasi ekonomi yang terjadi di Indonesia (Kementerian Perindustrian RI, 2012). Sebagai industri yang berbasis sumber daya alam, agroindustri memiliki potensi untuk mendorong pertumbuhan industri pengolahan dan meningkatkan perekonomian nasional (Bank Indonesia, 2017).

Agroindustri merupakan suatu kegiatan industri yang memanfaatkan hasil pertanian sebagai bahan baku, kemudian merancang, dan menyediakan peralatan serta jasa untuk kegiatan tersebut (Udayana, 2011). Dalam Peraturan Presiden No. 28 tahun 2008 tentang kebijakan industri nasional menyatakan bahwa agroindustri menjadi salah satu industri andalan masa depan karena sektor agroindustri ini didukung oleh ketersediaan bahan baku berupa sumber daya alam yang cukup melimpah di dalam negeri. Selain itu, hasil penelitian Priyarsono \& Backe (2007) menunjukkan bahwa agroindustri menjadi sektor yang dapat mendorong pertumbuhan ekonomi nasional menjadi lebih tinggi. Dikatakan pula bahwa agroindustri merupakan leading sector bagi pembangunan ekonomi Indonesia. Selain itu, penelitian Cahyanningsih (2019) di Provinsi Jawa Timur menunjukkan bahwa sektor agroindustri mempunyai peranan yang penting dalam mendorong pertumbuhan produksi sektor-sektor lain karena mempunyai kemampuan yang kuat untuk menarik pertumbuhan sektor hulu dan mendorong pertumbuhan output sektor hilir.

Berdasarkan potensi yang dimiliki oleh sektor agroindustri tersebut, maka pembangunan ekonomi yang berfokus pada agroindustri dapat menjadi strategi industrialisasi yang tepat bagi Indonesia. Upaya ini selaras dengan arah kebijakan industri nasional dan rencana strategis kementerian perindustrian berdasarkan visi misi pembangunan agroindustri yaitu terwujudnya agroindustri yang berdaya saing global pada tahun 2025. Akan tetapi, pentingnya sektor agroindustri ini ternyata belum diikuti dengan pengembangannya yang optimal. Berdasarkan Gambar 1, proporsi nilai tambah sektor agroindustri terhadap PDB nasional menunjukkan proporsi yang terus meningkat pada tahun 2014-2016. Namun, pada tahun 2017 dan 2018, proporsi nilai tambah sektor agroindustri tersebut terhadap PDB nasional justru mengalami penurunan. Selain itu, pertumbuhan sektor agroindustri (tahun dasar 2010) pada tahun 2011-2018 juga cenderung mengalami fluktuasi. Bahkan, terjadi perlambatan pertumbuhan sektor agroindustri pada beberapa tahun terakhir yaitu pada tahun 2013, 2015, 2016, dan 2018.

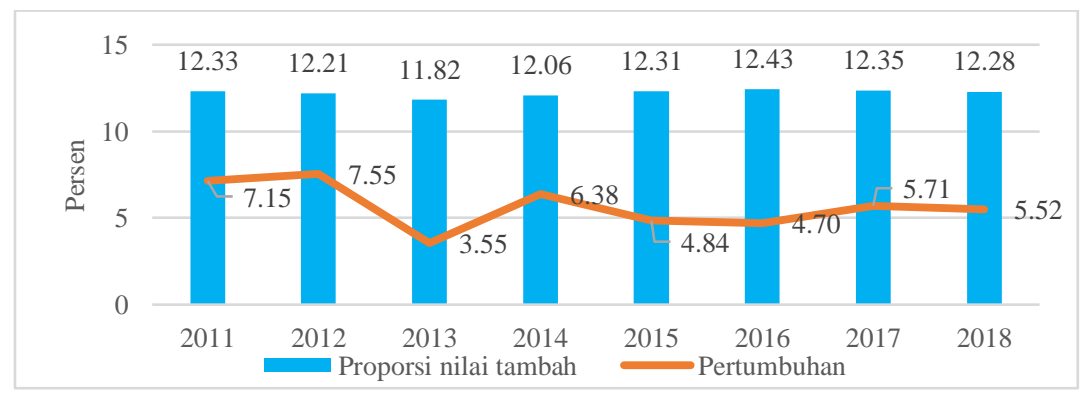

Sumber: Badan Pusat Statistik (BPS), diolah

Gambar 1. Proporsi nilai tambah dan pertumbuhan sektor agroindustri di Indonesia, 2011-2018. 
Kemudian, berdasarkan Laporan Akuntabilitas Kinerja Direktorat Jenderal Industri Agro Indonesia tahun 2015-2019, pertumbuhan dan kontribusi PDB sektor agroindustri masih belum mampu mencapai target yang telah ditetapkan. Selain itu, terdapat beberapa masalah dan tantangan yang dihadapi oleh sektor agroindustri sejalan dengan meningkatnya keinginan konsumen akan produk-produk yang berkualitas tinggi dan aman serta persaingan pasar baik di lokal maupun global yang semakin ketat.

Berdasarkan identifikasi masalah tersebut, maka dalam rangka mengoptimalkan pengembangan sektor agroindustri di Indonesia, diperlukan informasi secara komprehensif mengenai keadaan sektor agroindustri tersebut. Penelitian mengenai sektor agroindustri sudah pernah dilakukan oleh Cahyanningsih (2019) menganalisis sektor agroindustri di Jawa Timur dan Karkacier (2018) menganalisis sektor agroindustri di Provinsi Atalya, Turki dengan menggunakan metode analisis input-output. Selain itu, Siregar (2015) meneliti determinan output sektor agroindustri di Pulau Sulawesi Tahun 2002-2012 dengan metode regresi data panel. Akan tetapi, peneliti belum menemukan penelitian mengenai sektor agroindustri secara komprehensif dalam lingkup nasional di Indonesia dan dengan menggunakan Tabel Input-Output Indonesia yang terbaru tahun dasar 2016. Selain itu, peneliti juga belum menemukan penelitian mengenai sektor agroindustri dengan menggunakan metode input-output dan dilanjutkan ke metode regresi data panel.

Oleh karena itu, peneliti tertarik untuk melakukan penelitian secara komprehensif mengenai sektor agroindustri di Indonesia dengan mengkaji struktur input, struktur output, angka pengganda, dan subsektor unggulan dalam agroindustri yang dianalisis menggunakan Tabel Input-Output agroindustri updating tahun 2018. Setelah mendapatkan informasi subsektor unggulan tersebut, analisis dilanjutkan dengan menggunakan regresi data panel untuk mengetahui faktor-faktor input produksi yang memengaruhi output subsektor unggulan agroindustri. Adapun hipotesis yang digunakan dalam penelitian ini yaitu terdapat pengaruh positif dan signifikan baik secara keseluruhan maupun secara parsial antara faktor-faktor input produksi yang digunakan terhadap output subsektor unggulan agroindustri. Dengan demikian, melalui hasil penelitian ini akan dapat disajikan informasi yang komprehensif mengenai keadaan sektor agroindustri di Indonesia dan dapat menjadi pertimbangan bagi pemerintah untuk berfokus mengembangkan sektor agroindustri yang menjadi subsektor unggulan serta dapat mengambil kebijakan yang tepat agar sektor agroindustri dapat berkembang dengan optimal sehingga kinerja sektor industri pengolahan dapat meningkat.

\section{METODE}

\section{Landasan Teori}

Teori pertumbuhan ekonomi Kaldor (1968) dalam Kilavuz \& Topcu (2012) menjelaskan bahwa sektor industri manufaktur adalah mesin penggerak perekonomian nasional dan menjadikan sektor ini sebagai tujuan pembangunan nasional. Namun, masalah utama pembangunan negara sedang berkembang adalah keterbatasan pada modal dan sumber daya. Oleh karena itu Hirschman (1958) melalui teori pembangunan tidak seimbang memfokuskan pembangunan pada sektor unggulan yang akan merangsang perkembangan sektor-sektor lainnya (Pasaribu, 2015). Sektor industri yang menjadi fokus pembangunan dapat memproduksi suatu tingkat output tertentu dengan menggunakan berbagai kombinasi input faktor produksi yang dijelaskan dalam sebuah fungsi produksi salah satunya fungsi produksi Cobb-Douglas (1928). Fungsi produksi ini menggambarkan pembagian hasil produksi atau pendapatan yang konstan dari modal dan tenaga kerja (Rahim, 2016).

\section{Definisi Agroindustri}

Sukardi (2011) mengkaji lemahnya definisi agroindustri yang banyak dianut oleh kalangan akademisi terutama definisi agroindustri dari Austin (1992). Oleh karena itu, dengan pendekatan backward tracking, Sukardi memformulasikan definisi agroindustri sebagai industri yang menghasilkan produk-produk yang komponen utamanya berasal dari tanaman ataupun hewan. Komponen utama produk dapat diketahui dari arti penting keberadaan komponen tersebut mengkarakterisasi produk dan bukan oleh kuantitasnya.

\section{Ruang Lingkup Penelitian}

Penelitian ini menggunakan data runtun waktu tahunan dari tahun 2010-2018 dengan lokus penelitian di Negara Indonesia. Pengklasifikasian agroindustri yang digunakan yaitu berdasarkan klasifikasi agroindustri di bawah naungan Direktorat Jenderal Industri Agro Kementerian Perindustrian berdasarkan Peraturan Menteri Perindustrian RI No. 64 Tahun 2011. Selain itu, pengklasifikasian agroindustri juga berdasarkan konsep dan definisi agroindustri dari Sukardi (2011) dan didukung berdasarkan klasifikasi agroindustri dari penelitian 
Bernadi (2001), Amir (2014), dan Cahyanningsih (2019). Kemudian, agroindustri yang dicakup dalam penelitian ini hanya berskala besar dan sedang yang mempunyai tenaga kerja 20 orang atau lebih.

\section{Metode Pengumpulan Data}

Penelitian ini menggunakan data sekunder yang didapatkan dari Badan Pusat Statistik (BPS). Data-data yang digunakan dalam penelitian ini yaitu Tabel Input-Output Indonesia transaksi total atas dasar harga dasar tahun 2016, PDB menurut lapangan usaha dan menurut penggunaan atas dasar harga berlaku tahun 2016 dan 2018, dan data agroindustri dari publikasi Indikator Industri Manufaktur Indonesia tahun 2014 dan 2018 serta publikasi Statistik Industri Manufaktur Indonesia tahun 2010 sampai 2018.

\section{Metode Analisis}

Metode analisis yang digunakan dalam penelitian ini berupa analisis deskriptif dengan menggunakan Tabel Input-Output (I-O) dan analisis inferensia dengan menggunakan regresi data panel. Analisis Tabel I-O menggunakan Tabel I-O Indonesia tahun 2016 dalam 185 klasifikasi sektor yang dilakukan agregasi menjadi 26 klasifikasi sektor dan selanjutnya dilakukan updating dengan metode RAS hingga 100 iterasi dan menjadi Tabel I-O agroindustri Indonesia tahun 2018. Analisis Tabel I-O ini digunakan untuk mengetahui struktur output, struktur input, angka pengganda, dan subsektor unggulan dalam agroindustri. Setelah mendapatkan subsektor unggulan agroindustri, dilakukan analisis regresi data panel untuk mengetahui faktor-faktor yang memengaruhi output subsektor unggulan agroindustri dengan menggunakan individu golongan (3 digit KBLI 2015) subsektor unggulan agroindustri dan periode waktu tahun 2010 - 2018.

Persamaan regresi data panel yang digunakan dalam penelitian ini bersifat satu arah (one-way panel regression model) dan model regresi mengacu pada teori fungsi produksi Cobb-Douglas yang menjelaskan bahwa output sebagai fungsi dari input faktor produksi berupa tenaga kerja, modal, dan teknologi. Dalam penelitian ini, tenaga kerja digambarkan oleh penggunaan variabel jumlah tenaga kerja dan upah per tenaga kerja, modal digambarkan oleh pembentukan modal tetap dan penanaman modal (PMA dan PMDN), bahan bakar digambarkan oleh penggunaan bahan bakar, bahan baku digambarkan oleh penggunaan bahan baku impor dan teknologi digambarkan oleh penggunaan listrik. Oleh karena itu, spesifikasi model regresi data panel yang digunakan dalam penelitian ini adalah sebagai berikut.

$\ln (\text { Output })_{i t}=\alpha+\beta_{1} \ln \left(J m l_{-} T K\right)_{i t}+\beta_{2} \ln \left(U p h_{-} T K\right)_{i t}+\beta_{3} \ln (P M T)_{i t}+\beta_{4} P M_{i t}+\beta_{5} \ln (B B k r)_{i t}+$

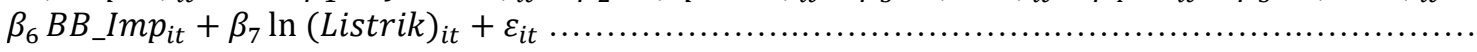

Keterangan:

$\alpha \quad$ : Intersep,

$\beta_{1}, \beta_{2} \ldots \beta_{7}$ : Koefisien regresi untuk masing-masing variabel independen,

Output $_{i t}$ : Nilai output dari subsektor unggulan agroindustri untuk golongan ke-i dan tahun ke-t,

$J m l \_T K_{i t}:$ Jumlah tenaga kerja subsektor unggulan agroindustri golongan ke-i dan tahun ke-t,

$U p h_{-} T K_{i t}$ : Upah per tenaga kerja subsektor unggulan agroindustri golongan ke-i \& tahun ke-t,

$P M T_{i t} \quad$ : Modal tetap subsektor unggulan agroindustri golongan ke-i dan tahun ke-t,

$P M_{i t} \quad$ : Persentase perusahaan yang status penanaman modalnya menggunakan PMDN atau PMA dari subsektor unggulan agroindustri untuk golongan ke-i dan tahun ke-t,

$B B k r_{i t} \quad$ : Nilai bahan bakar subsektor unggulan agroindustri golongan ke-i \& tahun ke-t,

$B B_{-} I m p_{i t}$ : Persentase bahan baku produksi yang diimpor untuk subsektor unggulan agroindustri pada golongan ke-i dan tahun ke-t,

Listrik $_{i t}$ : Nilai tenaga listrik yang dibeli baik dari PLN maupun non PLN untuk subsektor unggulan agroindustri golongan ke-i dan tahun ke-t,

$\varepsilon_{i t} \quad:$ Komponen error subsektor unggulan agroindustri golongan ke-i \& tahun ke-t,

$i \quad: 16$ golongan subsektor unggulan agroindustri,

$t \quad$ : tahun 2010, 2011,2012, .., 2018.

\section{HASIL DAN PEMBAHASAN}

\section{Analisis Tabel Input-Output Agroindustri}

\section{Struktur Output Agroindustri}

Berdasarkan tabel I-O agroindustri Indonesia updating tahun 2018, sektor agroindustri mampu menghasilkan nilai output sebesar 4.420.912.474 juta rupiah (16,49 persen) dari total output nasional yang 
berjumlah 26.809.788.181 juta rupiah. Dengan nilai output tersebut menjadikan sektor agroindustri sebagai sektor yang memberikan kontribusi terbesar terhadap total output nasional dibandingkan sektor lainnya. Kemudian, struktur penggunaan output sektor agroindustri lebih banyak digunakan sebagai konsumsi akhir yaitu sebesar 2.880.132.755 juta rupiah (55,58 persen) dibandingkan sebagai konsumsi antara yang sebesar 2.301.870.305 juta rupiah (44,42 persen). Hal ini menunjukkan bahwa output sektor agroindustri tidak banyak digunakan sebagai konsumsi untuk proses produksi melainkan lebih banyak digunakan sebagai konsumsi oleh konsumen akhir. Dari nilai konsumsi akhir tersebut, sebanyak 59,30 persen dikonsumsi oleh rumah tangga; 37,21 persen di ekspor; dan 3,49 persen digunakan sebagai konsumsi akhir lainnya meliputi konsumsi pemerintah, PMTB, dan perubahan inventori. Ditinjau dari struktur output masing-masing subsektor agroindustri yang ditunjukkan oleh Gambar 2, terlihat bahwa masing-masing subsektor memiliki karakteristik struktur output yang berbeda. Walaupun secara total output dari sembilan subsektor agroindustri sebagian besar digunakan sebagai konsumsi akhir, tetapi terdapat empat subsektor yang lebih banyak outputnya digunakan sebagai konsumsi antara. Hal ini menunjukkan bahwa kegiatan ekonomi subsektor tersebut memberikan kontribusi yang besar untuk kelanjutan proses produksi kegiatan ekonomi sektor lain karena output subsektor agroindustri tersebut digunakan oleh sektor lain sebagai input dalam proses produksinya.

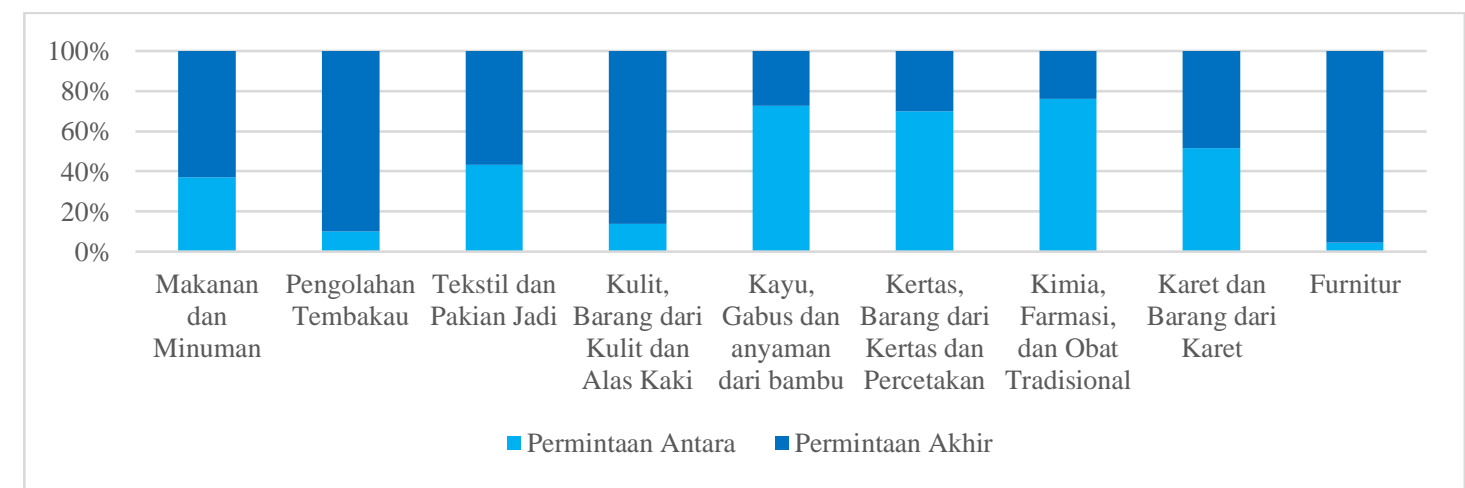

Sumber: Tabel I-O agroindustri Indonesia tahun 2018

Gambar 2. Struktur output subsektor dalam agroindustri Indonesia tahun 2018.

\section{Struktur Input Agroindustri}

Struktur penggunaan input dalam proses produksi dibagi menjadi dua yaitu input antara dan input primer. Struktur input sektor agroindustri didominasi oleh input antara yaitu sebesar 2.830.585.846 juta rupiah (64,58 persen) dibandingkan dengan Nilai Tambah Bruto (NTB) yang dihasilkan yaitu sebesar 1.552.747.608 juta rupiah (35,42 persen). Kondisi ini menunjukkan bahwa dalam proses produksinya, sektor agroindustri belum efisien karena pengeluaran untuk input antara seperti bahan baku lebih besar dibandingkan balas jasa atas pemakaian faktor-faktor produksinya. Dari nilai NTB sektor agroindustri tersebut, sebanyak 64,86 persen berupa surplus usaha bruto; 34,16 persen berupa kompensasi tenaga kerja; dan 0,98 persen berupa pajak dikurangi subsidi lainnya atas produksi.

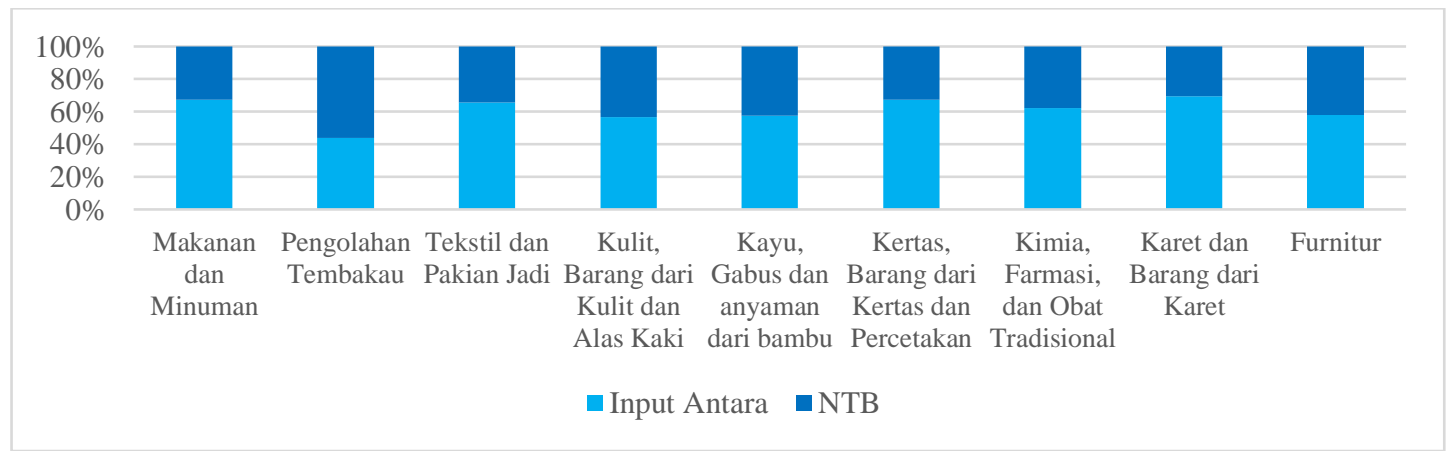

Sumber: Tabel I-O agroindustri Indonesia tahun 2018

Gambar 3. Struktur penggunaan input subsektor agroindustri Indonesia tahun 2018.

Kemudian, apabila ditinjau berdasarkan struktur input masing-masing subsektor agroindustri yang ditunjukkan oleh Gambar 3, terlihat bahwa hanya satu dari sembilan subsektor dalam agroindustri yang memiliki besaran nilai NTB yang dihasilkan lebih besar dari input antara yang digunakan yaitu subsektor industri pengolahan tembakau dengan struktur input berupa NTB sebesar 56 persen dan input antara sebesar 44 persen. Sementara itu, delapan subsektor agroindustri lainnya memiliki besaran penggunaan input antara melebihi NTB yang dihasilkan. 


\section{Angka Pengganda Output Agroindustri}

Melalui nilai pengganda output akan dapat dilihat dampak dari perubahan permintaan akhir pada suatu sektor terhadap perubahan output nasional. Berdasarkan Gambar 4, nilai pengganda output yang dimiliki oleh masing-masing subsektor agroindustri cukup tinggi yaitu berkisar 1,73 sampai 2,44. Adapun subsektor agroindustri yang memiliki nilai pengganda output terbesar adalah subsektor industri tekstil dan pakaian jadi sebesar 2,44. Nilai ini memiliki arti bahwa setiap penambahan permintaan akhir subsektor industri tekstil dan pakaian jadi sebesar 1 juta rupiah, maka total output nasional akan bertambah sebesar 2,44 juta rupiah.

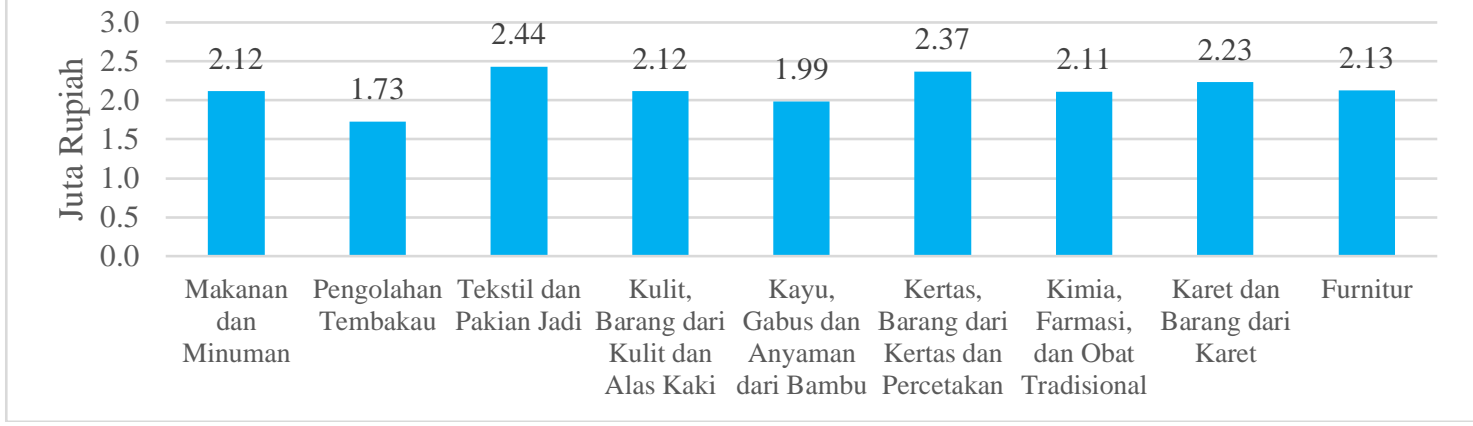

Sumber : Tabel I-O agroindustri tahun 2018

Gambar 4. Angka pengganda output subsektor agroindustri Indonesia tahun 2018.

\section{Analisis Keterkaitan Agroindustri}

Melalui analisis keterkaitan akan dilihat keterkaitan ke belakang dan keterkaitan ke depan dari sektor agroindustri. Nilai keterkaitan kebelakang dapat menunjukkan dampak dari peningkatan permintaan akhir di suatu sektor terhadap peningkatan output yang dihasilkan sektor hulunya. Sementara itu, nilai keterkaitan kedepan dapat menunjukkan dampak dari peningkatan output di suatu sektor terhadap permintaan akhir sektor hilirnya. Berdasarkan nilai keterkaitan ke belakang subsektor agroindustri yang ditunjukkan oleh Gambar 5, subsektor yang memiliki nilai keterkaitan ke belakang terbesar adalah subsektor industri tekstil dan pakaian jadi dengan nilai sebesar 2,44. Nilai ini memiliki arti bahwa jika terjadi peningkatan permintaan akhir pada subsektor industri tekstil dan pakaian jadi sebesar 1 juta rupiah, maka output total dari sektor-sektor lain ikut mengalami peningkatan sebesar 2,44 juta rupiah. Hal itu dapat terjadi karena subsektor industri tekstil dan pakaian jadi membutuhkan tambahan input agar bisa menghasilkan tambahan permintaan akhir.

Sementara itu, berdasarkan nilai keterkaitan ke depan, subsektor industri makanan dan minuman dan subsektor industri kimia, farmasi, dan obat tradisional merupakan dua subsektor dalam agroindustri yang memiliki nilai keterkaitan ke depan terbesar yaitu sebesar 2,38. Nilai ini menunjukkan bahwa setiap terjadi peningkatan output subsektor industri makanan dan minuman ataupun subsektor industri kimia, farmasi, dan obat tradisional sebesar 1 juta rupiah, maka total permintaan akhir sektor lain yang menggunakan output subsektor tersebut sebagai inputnya akan ikut meningkat sebesar 2,38 juta rupiah. Peningkatan tersebut terjadi sebagai akibat dari bertambahnya output subsektor industri makanan dan minuman ataupun subsektor industri kimia, farmasi, dan obat tradisional yang dapat digunakan sebagai input untuk sektor lain sehingga dapat mendorong sektor lain tersebut untuk meningkatkan produksinya.

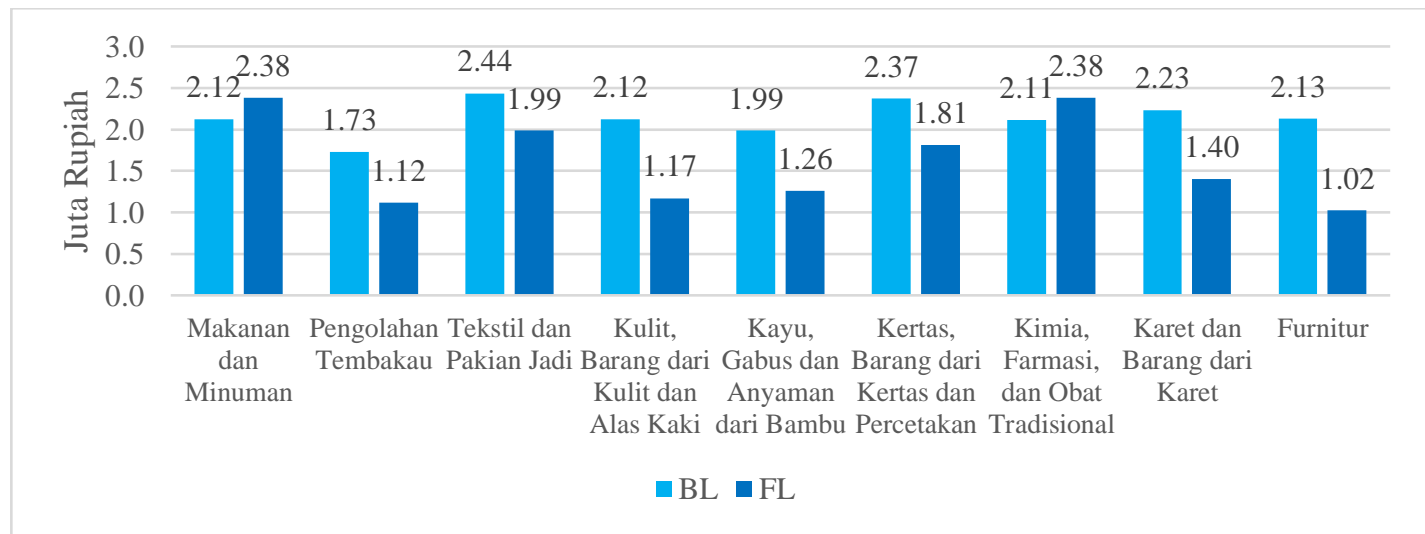

Sumber : Tabel I-O agroindustri Indonesia tahun 2018

Gambar 5. Keterkaitan ke belakang dan keterkaitan ke depan subsektor agroindustri Indonesia tahun 2018. 


\section{Subsektor Unggulan Agroindustri}

Subsektor unggulan agroindustri dapat diketahui dengan membandingkan nilai Indeks Daya Penyebaran (IDP) dan Indeks Derajat Kepekaan (IDK) yang dimiliki oleh setiap sektor. Berdasarkan nilai IDP, delapan dari sembilan subsektor agroindustri memiliki nilai keterkaitan ke belakang di atas rata-rata dari seluruh sektor yang ada. Hal tersebut memperlihatkan bahwa sektor agroindustri banyak menggunakan output dari sektor lain sebagai input. Namun berdasarkan nilai IDK, hanya terdapat tiga subsektor dalam agroindustri yang memiliki keterkaitan ke depan diatas rata-rata. Hal tersebut menunjukkan bahwa output sektor agroindustri masih jarang digunakan sebagai input untuk produksi oleh sektor lain. Kondisi ini bersesuaian dengan hasil struktur output sektor agroindustri yang menunjukkan bahwa sebagian besar subsektor dalam agroindustri memproduksi barang dan jasa untuk konsumsi akhir.

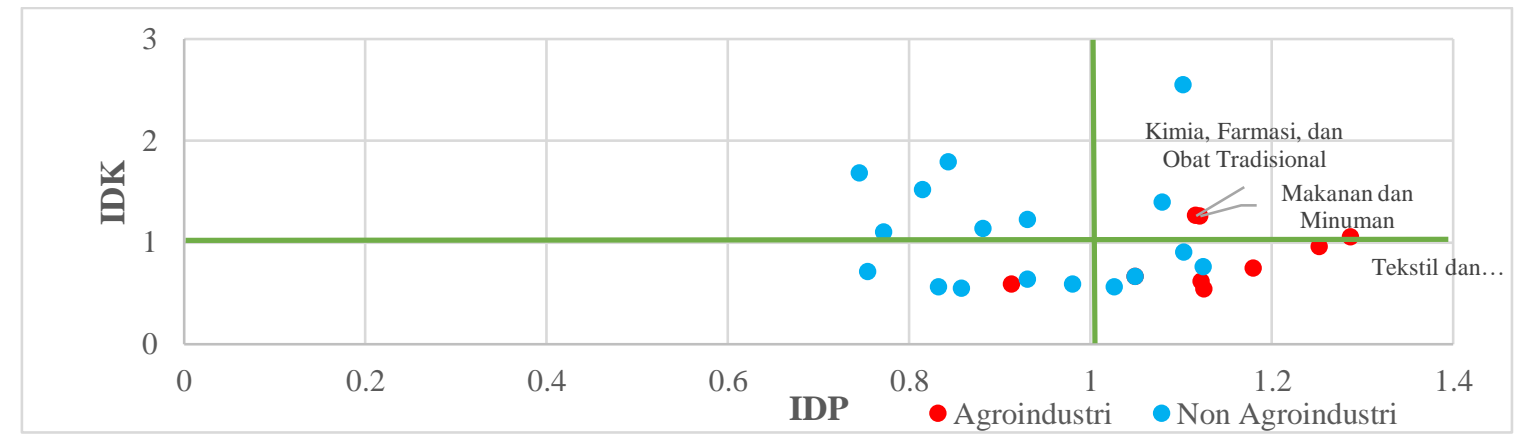

Sumber: Tabel I-O agroindustri Indonesia tahun 2018

Gambar 6. Tipologi klassen sektor ekonomi berdasarkan IDP dan IDK di Indonesia tahun 2018.

Berdasarkan nilai IDP dan IDK secara keseluruhan yang ditunjukkan Gambar 6, terdapat tiga subsektor agroindustri yang memiliki nilai IDP dan IDK diatas rata-rata yaitu subsektor industri makanan dan minuman; industri tekstil dan pakaian jadi; dan industri kimia, farmasi, dan obat tradisional. Hal tersebut menunjukkan bahwa ketiga subsektor tersebut dapat menjadi subsektor unggulan dalam agroindustri. Maka dari itu, pemerintah dapat memulai pengembangan sektor agroindustri dengan memfokuskan perhatian pada ketiga subsektor agroindustri tersebut. Hal ini dikarenakan ketiga subsektor agroindustri tersebut dapat memberikan dampak atas keterkaitan ke belakang dan keterkaitan ke depan yang besar besar terhadap sektor lain. Hasil analisis ini didukung dan sejalan dengan peta jalan Making Indonesia 4.0 Kementerian Perindustrian, di mana ketiga subsektor agroindustri tersebut masuk ke dalam lima sektor industri manufaktur yang menjadi prioritas dalam pengembangannya untuk mengimplementasikan revolusi industri generasi keempat di Indonesia.

\section{Analisis Regresi Data Panel}

Setelah mendapatkan informasi subsektor unggulan agroindustri yang didapatkan dari analisis Tabel I-O sektor agroindustri, maka untuk mengetahui faktor-faktor yang memengaruhi outputnya dilakukan analisis dengan menggunakan regresi data panel. Periode waktu yang digunakan dari tahun 2010 sampai 2018 dengan individu berupa golongan (3 digit KBLI 2015) dalam subsektor unggulan agroindustri. Pemilihan model terbaik dalam regresi data panel diawali dengan melakukan uji Chow untuk menentukan apakah model terbaik fixed effect atau common effect. Kemudian dilanjutkan dengan melakukan uji Hausman untuk menentukan apakah model terbaik fixed effect atau random effect. Berdasarkan hasil kedua pengujian tersebut, dengan taraf taraf uji $(\alpha)=0,05$, dapat disimpulkan bahwa model terbaik yang terpilih adalah Fixed Effect Model (FEM).

FEM adalah model terpilih, maka pengujian dilanjutkan dengan uji struktur matriks varians-kovarians residual dengan menggunakan uji Lagrange Multiplier (LM) dan uji $\lambda_{\text {LM. }}$. Hasilnya, struktur varians-kovarians residual model bersifat heteroskedastis dan terdapat cross-sectional correlation, sehingga metode estimasi yang digunakan adalah FGLS Cross Section SUR (PCSE). Salah satu kelebihan dari metode estimasi ini adalah dapat mengakomodasi masalah heteroskedastisitas dan autokorelasi (Greene, 2012), untuk itu pengujian asumsi yang perlu dilakukan hanya normalitas dan non-multikolinearitas. Pengujian asumsi normalitas menggunakan uji Jarque-Bera dengan hipotesis nol nya adalah residual dalam model berdistribusi normal. Didapatkan $p$-value uji Jarque-Bera sebesar 0,7478 lebih besar dari taraf uji $(\alpha)=0,05$ sehingga menghasilkan keputusan gagal tolak $\mathrm{H}_{0}$, maka asumsi normalitas terpenuhi. Pengujian non-multikolinearitas dilakukan dengan melihat nilai Variance Inflation Factor (VIF) setiap variabel independen. Didapatkan nilai VIF dari setiap variabel independen kurang dari sepuluh sehingga asumsi non-multikolinearitas terpenuhi.Setelah memenuhi semua asumsi klasik, maka tahap selanjutnya adalah menganalisis variabel-variabel yang memengaruhi perubahan output subsektor unggulan agroindustri berdasarkan model yang digunakan. 
Tabel 1. Ringkasan output hasil estimasi model regresi data panel.

\begin{tabular}{cccc}
\hline Variabel & Koefisien & t-statistic & $p$-value \\
\hline C & 4,6950 & 2,3054 & 0,0228 \\
LN(JML_TK) & 1,0348 & 6,5809 & 0,0000 \\
LN(UPH_TK) & 0,1628 & 1,6108 & 0,1098 \\
LN(PMT) & 0,0477 & 2,4369 & 0,0163 \\
PM & 0,0322 & 3,5018 & 0,0006 \\
LN(BBKR) & 0,1541 & 2,0486 & 0,0427 \\
BB_IMP & $-0,0047$ & $-0,8392$ & 0,4030 \\
LN(LISTRIK) & 0,0645 & 2,4493 & 0,0157 \\
\hline Golongan Industri 101 & \multicolumn{2}{|c}{ Efek Individu } & $-0,6323$ \\
Golongan Industri 102 & 0,3671 & Golongan Industri 110 & $-0,4951$ \\
Golongan Industri 103 & $-0,1464$ & Golongan Industri 131 & $-0,3366$ \\
Golongan Industri 104 & 0,0074 & Golongan Industri 139 & $-1,0618$ \\
Golongan Industri 105 & $-0,2930$ & Golongan Industri 141 & $-0,2438$ \\
Golongan Industri 106 & 0,9767 & Golongan Industri 143 & 0,3605 \\
Golongan Industri 107 & 1,2301 & Golongan Industri 201 & $-0,1799$ \\
Golongan Industri 108 & $-0,4027$ & Golongan Industri 202 & $-0,1334$ \\
\hline R-squared & 0,9833 & Golongan Industri 210 & \\
\hline Adjusted R-squared & Ringkasan Statistik & \\
\hline
\end{tabular}

Berdasarkan Tabel 1, estimasi persamaan regresi data panel yang terbentuk adalah sebagai berikut : $\ln (\text { Output })_{i t}=\left(4,695+\mu_{\mathrm{i}}\right)^{*}+1,0348 \ln \left(J m l_{-} T K\right)_{i t}^{*}+0,1628 \ln \left(U p h_{-} T K\right)_{i t}+0,0477 \ln (P M T)_{i t}^{*}+$ $0,0322 P M_{i t}^{*}+0,1541 \ln (B k r)_{i t}^{*}-0,0047$ BB_Imp $p_{i t}+0,0645 \ln (\text { Listrik) })_{i t}^{*} \ldots$

Keterangan: "signifikan pada $\alpha=0,05 \& \mu_{\mathrm{i}}$ adalah efek individu golongan subsektor unggulan agroindustri

Berdasarkan Tabel 1, nilai adjusted $R$-squared yang dihasilkan sebesar 0,9605 yang menunjukkan bahwa 96,05 persen keragaman output subsektor unggulan agroindustri dapat dijelaskan oleh variabel-variabel independen di dalam model sedangkan sisanya 3,95 persen dijelaskan oleh variabel-variabel lain yang belum masuk dalam model. Kemudian, uji simultan melalui uji F menghasilkan p-value sebesar 0,0000 lebih kecil dari taraf uji $(\alpha)=0,05$, sehingga menghasilkan keputusan tolak $\mathrm{H}_{0}$. Artinya, minimal terdapat satu variabel independen yang berpengaruh signifikan terhadap output subsektor unggulan agroindustri.

Pengujian selanjutnya yaitu uji t parsial untuk mengetahui variabel independen apa saja yang memiliki pengaruh secara parsial dan signifikan terhadap output subsektor unggulan agroindustri. Nilai $t$-statistic jumlah tenaga kerja, pembentukan modal tetap, status penanaman modal PMDN atau PMA, penggunaan bahan bakar, dan penggunaan listrik menunjukkan angka lebih besar dari $t_{0,05(121)}=1,6575$ memberikan keputusan tolak $\mathrm{H}_{0}$ yang berarti variabel-variabel tersebut berpengaruh positif dan signifikan terhadap output subsektor unggulan agroindustri. Sedangkan untuk variabel upah tenaga kerja dan persentase bahan baku impor tidak memiliki pengaruh positif secara signifikan terhadap output subsektor unggulan agroindustri.

Variabel jumlah tenaga kerja yang dipekerjakan oleh perusahaan memiliki hubungan yang positif dan signifikan terhadap output subsektor unggulan agroindustri. Nilai koefisien yang dihasilkan sebesar 1,0348 yang mempunyai arti bahwa jika jumlah tenaga kerja yang dipekerjakan meningkat sebesar 1 persen, maka output subsektor unggulan agroindustri akan meningkat sebesar 1,0348 persen dengan asumsi variabel lainnya konstan. Besaran koefisien yang positif memperlihatkan bahwa variabel tenaga kerja elastis dan berperan penting terhadap perubahan variabel output. Dengan demikian, hasil analisis ini menunjukkan bahwa golongan industri yang termasuk subsektor unggulan agroindustri merupakan industri yang padat karya.

Kemudian, variabel perubahan modal tetap memiliki pengaruh positif dan signifikan terhadap perubahan output subsektor unggulan agroindustri. Hasil ini menunjukkan bahwa dalam subsektor unggulan agroindustri, modal fisik dalam pembentukan modal tetap yang mencakup gedung, mesin dan perlengkapannya, kendaraan, perangkat lunak dan modal tetap lainnya yang dimiliki oleh perusahaan sebagai aset untuk mendukung proses produksi secara bersama-sama berpengaruh signifikan terhadap output yang dihasilkan. Nilai koefisien yang dihasilkan sebesar 0,0477 yang mempunyai arti bahwa jika nilai pembentukan modal tetap meningkat sebesar 1 persen, maka output subsektor unggulan agroindustri akan meningkat sebesar 0,0477 persen dengan asumsi 
variabel lainnya konstan. Selanjutnya, variabel persentase perusahaan yang status penanaman modalnya dari PMDN maupun PMA memiliki pengaruh yang positif dan signifikan terhadap output subsektor unggulan agroindustri. Nilai koefisien yang dihasilkan sebesar 0,0322 yang mempunyai arti bahwa jika persentase perusahaan yang penanaman modalnya dari PMDN ataupun PMA meningkat sebesar 1 persen, maka output subsektor unggulan agroindustri akan meningkat sebesar 3,22 persen dengan asumsi variabel lainnya konstan. Dengan adanya penambahan penanaman modal akan dapat mengganti bagian dari penyediaan modal yang rusak ataupun sebagai tambahan penyediaan modal yang ada.

Kemudian, variabel bahan bakar yang digunakan oleh perusahaan memiliki hubungan yang positif dan signifikan terhadap output subsektor unggulan agroindustri. Nilai koefisien yang menunjukkan bahwa jika nilai bahan bakar yang digunakan meningkat sebesar 1 persen, maka output subsektor unggulan agroindustri akan meningkat sebesar 0,1541 persen dengan asumsi variabel lainnya konstan. Hal ini karena bahan bakar dan pelumas merupakan salah satu faktor penting dalam suatu proses produksi karena menjadi sumber tenaga untuk menggerakan mesin-mesin produksi. Selanjutnya, variabel listrik yang digunakan oleh perusahaan sebagai pendekatan dalam melihat kemajuan teknologi memiliki hubungan yang positif dan signifikan terhadap output subsektor unggulan agroindustri. Nilai koefisien yang dihasilkan sebesar 0,0645 mempunyai arti bahwa jika nilai listrik yang digunakan meningkat sebesar 1 persen, maka output subsektor unggulan agroindustri akan meningkat sebesar 0,0645 persen dengan asumsi variabel lainnya konstan. Hasil analisis ini menunjukkan bahwa penggunaan teknologi yang menggunakan listrik seperti mesin-mesin produksi memiliki pengaruh yang signifikan terhadap output yang dihasilkan oleh subsektor unggulan agroindustri.

Sementara itu, variabel upah per tenaga kerja memiliki pengaruh positif namun tidak signifikan terhadap perubahan output subsektor unggulan agroindustri. Kondisi ini dapat terjadi karena sistem pengupahan yang diterapkan pada sebagian besar perusahaan industri besar-sedang di Indonesia masih menggunakan sistem upah bulanan untuk pekerja tetap dan upah harian untuk pekerja tidak tetap. Para pekerja diberikan upah sesuai dengan aturan upah minimum yang berlaku di wilayah masing-masing yang menyebabkan perubahan tingkat upah yang terjadi tidak akan memengaruhi produktivitas dari pekerja karena besaran upah yang diterima oleh pekerja telah diatur sedemikian rupa. Kemudian, persentase penggunaan bahan baku impor memiliki pengaruh negatif namun juga tidak signifikan terhadap perubahan output subsektor unggulan agroindustri. Hal ini dapat terjadi karena impor bahan baku yang dilakukan oleh perusahaan pada industri-industri tersebut tidak dilakukan secara konsisten sehingga dapat meningkatkan biaya input produksi. Hal ini akan berdampak pada semakin berkurangnya margin keuntungan dan berdampak pada penurunan produktivitas perusahaan sehingga output menurun. Hasil ini bersesuaian dengan struktur input sektor agroindustri hasil analisis Tabel I-O yang menunjukkan penggunaan input antara sektor agroindustri melebihi NTB yang dihasilkan. Kondisi ini menunjukkan sebagian besar kegiatan dalam industri-industri tersebut belum melakukan produksi dengan efisien karena pengeluaran untuk input antara seperti bahan baku lebih besar dibandingkan dengan balas jasa faktor produksinya. Sementara itu, berdasarkan efek individu, terdapat enam golongan dalam subsektor unggulan agroindustri memiliki nilai efek individu positif atau rata-rata perubahan outputnya diatas rata-rata seluruh golongan dan terdapat sepuluh golongan industri yang memiliki nilai efek individu negatif.

\section{KESIMPULAN}

Berdasarkan analisis tabel I-O agroindustri yang telah dibahas sebelumnya, dapat disimpulkan bahwa struktur output sektor agroindustri di Indonesia lebih banyak digunakan sebagai konsumsi akhir dibandingkan sebagai konsumsi antara. Sementara itu, struktur inputnya didominasi oleh input antara dibandingkan dengan NTB yang dihasilkan. Hal tersebut menunjukkan bahwa sektor agroindustri belum mampu melakukan produksi dengan efisien akibat dari pengeluaran untuk input antara yang lebih besar dibandingkan balas jasa faktor produksinya. Ditinjau dari angka pengganda output, masing-masing subsektor agroindustri memiliki nilai yang cukup tinggi. Sebagian besar subsektor agroindustri memiliki nilai keterkaitan ke belakang yang lebih besar dibandingkan keterkaitan kedepannya. Ini menunjukkan bahwa sektor agroindustri memiliki keterkaitan besar terhadap sektor lain yang menjadi inputnya, namun output sektor agroindustri belum banyak digunakan sebagai input oleh sektor lain. Berdasarkan nilai Indeks Daya Penyebaran (IDP) dan Indeks Derajat Kepekaan (IDK), terdapat tiga subsektor agroindustri yang memiliki nilai IDP dan IDK diatas rata-rata yaitu subsektor industri makanan dan minuman; industri tekstil dan pakaian jadi; dan industri kimia, farmasi, dan obat tradisional. Dengan demikian, ketiga industri tersebut dapat menjadi subsektor unggulan dalam agroindustri. Selanjutnya, dari hasil regresi data panel, terdapat pengaruh yang positif dan signifikan antara jumlah tenaga kerja, pembentukan modal tetap, status penanaman modal PMDN ataupun PMA, penggunaan bahan bakar, dan penggunaan listrik terhadap output subsektor unggulan agroindustri, sedangkan variabel upah per tenaga kerja dan penggunaan bahan baku impor tidak memiliki pengaruh yang positif dan signifikan. 
Berdasarkan kesimpulan dari hasil penelitian ini, maka penulis menyarankan agar pemerintah dapat membuat kebijakan pendukung agar sektor agroindustri dapat melakukan produksi dengan efisien. Kebijakan tersebut seperti memberikan subsidi untuk menurunkan harga bahan baku dan kebijakan aglomerasi agroindustri untuk mengurangi jarak dalam memperoleh bahan baku dan kestabilan pasokannya dapat terjaga. Kemudian, pemerintah dapat lebih memprioritaskan pengembangan pada agroindustri yang menjadi subsektor unggulan. Upaya-upaya yang dapat dilakukan seperti dari sisi bahan baku, pemerintah dapat lebih mengoptimalkan penggunaan bahan baku lokal melalui kebijakan substitusi impor. Pendekatan yang dapat dilakukan seperti pemberian fasilitas sarana dan prasarana ataupun insentif serta penggunaan teknologi tepat guna bagi pihak penyedia bahan baku. Kemudian dari sisi permodalan, pelaku agroindustri dan pemerintah sebaiknya saling bekerja sama untuk menggencarkan promosi agroindustri khususnya subsektor unggulan agroindustri kepada para investor terutama untuk penanaman modal dari luar negeri dikarenakan jumlahnya masih sedikit. Kebijakan yang dapat diambil seperti dengan memperbaiki iklim investasi melalui kepastian regulasi karena investor asing terkadang ragu melakukan investasi akibat regulasi yang dinilai kurang kondusif. Terakhir, untuk peneliti selanjutnya dapat menggunakan analisis Input-Output multi region dan Social Accounting Matrix (SAM) serta dapat mencakup agroindustri skala mikro dan kecil.

\section{DAFTAR PUSTAKA}

Amir, A. (2014). Potensi Klaster Agroindustri Usaha Mikro Kecil dan Menengah di Provinsi Jambi. Jurnal Perspektif Pembiayaan dan Pembangunan Daerah, 2(1), 9-20.

Arifin. (2018). Pengaruh Faktor Internal dan Eksternal Dalam Fenomena Deindustrialisasi di Indonesia Tahun 2002-2017: Pendekatan Metode ARDL. Skripsi Politeknik Statistika STIS. Jakarta.

Austin, J. E. (1992). Agroindustrial Project Analysis Criritcal Design Factors Second Edition. Geometric Design of Roads Handbook. The johns Hpkins University Press. Baltimore.

Bernadi, A. H. (2001). Analisis Peranan Sektor Agroindustri dalam Perekonomian Indonesia (Analisis InputOutput).Institut Pertanian Bogor. Bogor.

Cahyanningsih, H. (2019). Analisis Peranan Agroindustri Terhadap Perekonomian Provinsi Jawa Timur. Universitas Jember. Jember.

Dewi, D. A. (2010). Deindustrialisasi di Indonesia 1983-2008: Analisis dengan Pendekatan Kaldorian. Thesis Pasca Sarjana Agriculture Economics.

Greene, W. H. (2012). Econometric Analysis Seventh Edition. Pearson. New York.

Indonesia, B. (2017). Kajian Ekonomi dan Keuangan Regional Laporan Nusantara Agustus 2017, Volume 12.

Jalilian, H., \& Weiss, J. (2000). De-industrialisation in Sub-Saharan Africa: Myth or crisis? Journal of African Economies, 9(1), 24-43.

Karkacier, O. (2018). The Input-Output Analysis of Agro-Industries in Antalya. Turkish Journal of Agriculture - Food Science and Technology (TURJAF), 6(6), 740-748.

Kilavuz, E., \& Topcu, B. A. (2012). Export and Economic Growth in the Case of the Manufacturing Industry: Panel Data Analysis of Developing Countries. International Journal of Economics and Financial Issues, 2(2), 201-215.

Pasaribu, R. B. F. (2015). Ekonomi Pembangunan. Bahan Ajar, Rows Collection.

Priyarsono, D. S., \& Backe, D. (2007). Industri Berbasis Pertanian: Arah Pengembangan Industri di Indonesia. Soca, 8(3), 256-264.

Rahim, A. (2016). Landasan Teori Ekonomi dengan Model Fungsi Persamaan. PKBM Rumah Buku Carabaca. Makassar.

RI, K. P. (2012). Outlook Industri 2012: Strategi Percepatan dan Perluasan Agroindustri. Kementerian Perindustrian RI. Jakarta.

Siregar, Ayu Pinta Gabena. (2015). Industri Agro dan Faktor-Faktor yang Memengaruhi Outputnya di Pulau Sulawesi Tahun 2002-2012. Skripsi Politeknik Statistika STIS. Jakarta.

Sujiatmiko, E. (2018). INDEF: Indonesia Alami Deindustrialisasi. Retrieved November 15, 2020, from https://www.antaranews.com/berita/722683/indef-indonesia-alami-deindustrialisasi

Sukardi. (2011). Formulasi Definisi Agroindustri dengan Pendekatan Backward Tracking. Jurnal Pangan, 20(3), 269-282.

Tambunan, M dan Priyanto, S. (2005). Perubahan Struktur Ekonomi dan Peranan Agroindustri dalam Proses Industrialisasi Pertanian di Indonesia. Kerjasama Kanisius dan ISEI. Jakarta.

Tambunan, T. (2000). Perekonomian Indonesia. Jakarta: Ghalia Indonesia.

Udayana,I.G.B. (2011). PAgroindustri dalam Pembangunan Pertanian. Journal Singhadwala,44, pp. 3-8. 